\title{
Pendeo-Epitaxy of Gallium Nitride and Aluminum Nitride Films and Heterostructures on Silicon Carbide Substrate
}

\author{
T. Gehrke, K. J. Linthicum, D. B. Thomson, P. Rajagopal, A. D. Batchelor *, R. F. Davis \\ Department of Materials Science and Engineering \\ * Analytical Instrumentation Facility \\ North Carolina State University \\ Box 7907 \\ Raleigh, NC 27695-7907
}

Cite this article as: MRS Internet J. Semicond. Res. 4S1, G3.2 (1999)

\begin{abstract}
Pendeo-epitaxy of individual $\mathrm{GaN}$ and $\mathrm{Al}_{x} \mathrm{Ga}_{1-\mathrm{x}} \mathrm{N}$ films and single- and multi-layer heterostructures of these materials have been achieved on a columnar $\mathrm{GaN}$ seed layer using metallorganic vapor phase epitaxy. These structures have been characterized using scanning electron microscopy and atomic force microscopy. The RMS roughness value of the grown side wall plane $(1 \overline{1} \overline{2} 0)$ of these structures was $0.099 \mathrm{~nm}$.
\end{abstract}

\section{INTRODUCTION}

Recent topics of focused research in the III-Nitride community have been the selective area growth coupled with lateral epitaxial overgrowth (LEO) and the application of this tandem process route to reduce the dislocation density of $\mathrm{GaN}$ films by several orders of magnitude in the overgrown areas. A new form of selective and lateral growth, namely 'pendeo (from the Latin: to hang or be suspended ) -epitaxy' has been recently pioneered in our group ${ }^{1-3}$, to achieve large area growth of III-N films having a continuous low dislocation density over the entire surface. This process route is based on the growth of GaN off a side wall and the ability to laterally overgrow a mask that has been employed to stop vertical propagation of line and planar defects. Additional details of this procedure and the initial results of this research have been reported previously ${ }^{4,5}$.

In this paper we report the growth via pendeo-epitaxy of layered thin film structures consisting of $\mathrm{GaN}$ and $\mathrm{Al}_{x} \mathrm{Ga}_{1-\mathrm{x}} \mathrm{N}$. The following sections describe the experimental procedure necessary to achieve layered structures by this technique in detail and discuss the results and conclusion of this study.

\section{EXPERIMENTAL PROCEDURE}

Layered structures containing $\mathrm{GaN}$ and $\mathrm{Al}_{\mathrm{x}} \mathrm{Ga}_{1-\mathrm{x}} \mathrm{N}$ have been grown on a $0.5 \mu \mathrm{m}$ to $1.0 \mu \mathrm{m}$ thick $\mathrm{GaN}$ seed layer grown on a high temperature, $100 \mathrm{~nm}$ thick AlN buffer layer previously deposited on a $6 \mathrm{H}-$ $\mathrm{SiC}(0001)$ substrate. All layers were grown using a cold-wall, vertical pancake style, RF-inductively heated metalorganic vapor phase epitaxy (MOVPE) system. The AlN buffer layers and the hexagonal GaN seed layers were each grown within the susceptor temperature ranges of $1080^{\circ} \mathrm{C}-1120^{\circ} \mathrm{C}$ and $980^{\circ} \mathrm{C}$ $1020^{\circ} \mathrm{C}$, respectively, at a total pressure of 45 Torr. Triethylaluminum $(20-25 \mu \mathrm{mol} / \mathrm{min})$, triethylgallium (23-29 $\mu \mathrm{mol} / \mathrm{min})$, and $\mathrm{NH}_{3}(1.5 \mathrm{slm})$ precursors were used in combination with a $\mathrm{H}_{2}(3 \mathrm{slm})$ diluent. A 100 $\mathrm{nm}$ thick silicon nitride layer, employed as a growth mask for blocking the continued threading dislocations during the pendeo-epitaxial growth stage, was deposited using a plasma enhanced chemical vapor 
deposition (PECVD) system. A $150 \mathrm{~nm}$ layer of nickel was subsequently deposited as an etch mask and patterned in $\langle 1100\rangle$ oriented stripes using standard photolithography techniques. Two different masks were used to produce (a) $2 \mu \mathrm{m}$ wide stripes with a spacing of $3 \mu \mathrm{m}$, and (b) $3 \mu \mathrm{m}$ wide stripes with a spacing of $7 \mu \mathrm{m}$. An inductively coupled plasma (ICP) etching system was employed to achieve the desired microstructures via (a) RF-sputtering of the exposed nickel stripes in an Ar-plasma and (b) ICP-etching of columnar forms in the $\mathrm{GaN}$ seed layers using a combination of $\mathrm{Cl}_{2}$ and $\mathrm{BCl}_{3}$. Etching was continued into the $\mathrm{SiC}$ substrate, which completely exposed each $\mathrm{GaN}$ column. Residual Ni was removed after etching by dipping in $\mathrm{HNO}_{3}$. The samples were cleaned sequentially in tricloroethylene, acetone, methanol, and hydrochloric acid. The pendeo-epitaxial growth of the $\mathrm{GaN}$ and the $\mathrm{Al}_{\mathrm{x}} \mathrm{Ga}_{1-\mathrm{x}} \mathrm{N}$ layers were achieved within the susceptor temperature range of $1050-1100^{\circ} \mathrm{C}$ and $1080-1120^{\circ} \mathrm{C}$, respectively, and at atal pressure of 45 Torr. Triethylgallium $(23-27 \mu \mathrm{mol} / \mathrm{min})$ and $\mathrm{NH}_{3}(1.5 \mathrm{slm})$ precursors were again used in combination with a $\mathrm{H}_{2}$ diluent $(3 \mathrm{slm}$ ). The introducing of triethylaluminum at flow rates of $2.5 \mu \mathrm{mol} / \mathrm{min}$ and 5.8 $\mu \mathrm{mol} / \mathrm{min}$, respectively, into the growth chamber produced $\mathrm{Al}_{\mathrm{x}} \mathrm{Ga}_{1-\mathrm{x}} \mathrm{N}$ layers contained an $\mathrm{Al}$ concentration of approximately $5 \%$ and $10 \%$.

A JEOL 6400 FE scanning electron microscope (SEM) and an Digital Instruments, Inc. Dimension 3000 atomic force microscope (AFM) operating in the tappingMode ${ }^{\mathrm{TM}}$ with an Olympus tapping mode etched silicon probe were employed for microstructural characterization.

\section{RESULTS AND DISCUSSION}

Figure 1 shows a schematic flow diagram of the process route for achieving pendeo-epitaxial growth of continuous layers of (c) $\mathrm{GaN}$ or (e) $\mathrm{Al}_{\mathrm{x}} \mathrm{Ga}_{1-\mathrm{x}} \mathrm{N}$. The intermediate steps in this approach can also be used to achieve the growth of (d) a double layer heterostructure of $\mathrm{GaN}$ and $\mathrm{Al}_{\mathrm{x}} \mathrm{Ga}_{1-\mathrm{x}} \mathrm{N}$, and a subsequent growth of (e) a continuous coalesced layer of $\mathrm{Al}_{x} \mathrm{Ga}_{1-\mathrm{x}} \mathrm{N}$ or (f) a layered double heterostructure of GaN/ $\mathrm{Al}_{\mathrm{x}} \mathrm{Ga}_{1-\mathrm{x}} \mathrm{N} / \mathrm{GaN}$.

Each of the microstructures depicted in Figure 1 has been realized in this research, as shown in Figure 2. The scanning electron micrographs in the latter figure illustrate (a) the $\left\langle 1 \overline{1}^{-} 00\right\rangle$ oriented columnar forms in a GaN seed layer, (b) simultaneous lateral growth of $\mathrm{GaN}$ from the side walls lateral overgrowth of the silicon nitride mask during pendeo-epitaxy, (c) a continuous, coalesced layer of GaN, (d) a bi-layer structure of $\mathrm{GaN}$ and $\mathrm{Al}_{10} \mathrm{Ga}_{90} \mathrm{~N}$, (e) a continuous coalesced layer of $\mathrm{Al}_{10} \mathrm{Ga}_{90} \mathrm{~N}$, and (f) a layered structure of $\mathrm{GaN} / \mathrm{Al}_{10} \mathrm{Ga}_{90} \mathrm{~N} / \mathrm{GaN}$. 


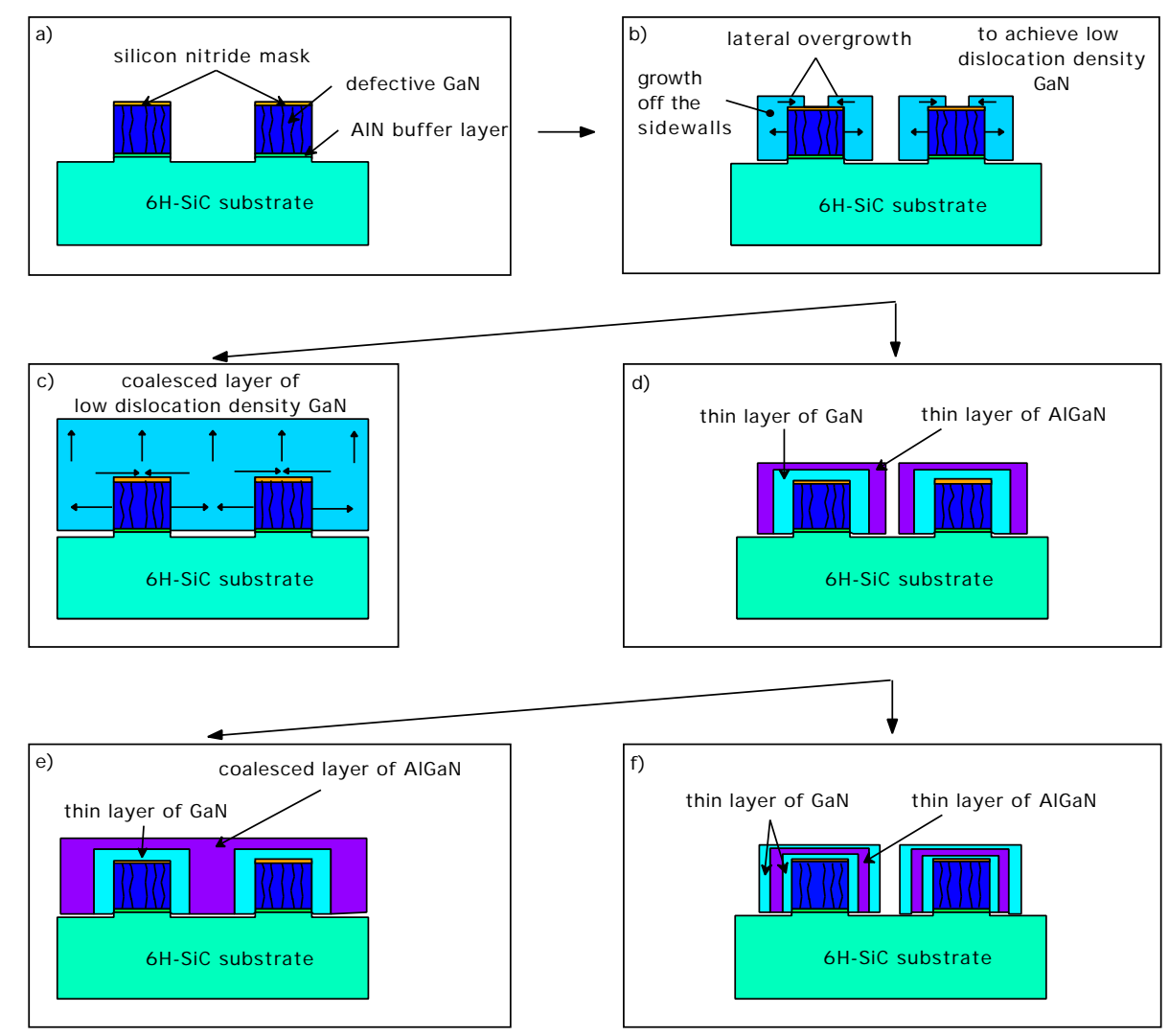

Figure 1. Schematic flow diagram showing the steps from (a) the etched columnar forms in the GaN seed layers to (b) lateral growth off the side walls of the seed layer and lateral overgrowth over the silicon nitride mask, to the growth of either (c) a continuous coalesced GaN film, or (d) a discrete bi-layer of $\mathrm{GaN}$ and $\mathrm{Al}_{\mathrm{x}} \mathrm{Ga}_{1-\mathrm{x}} \mathrm{N}$ from which further growth results in either (e) a continuous coalesced layer of $\mathrm{Al}_{\mathrm{x}} \mathrm{Ga}_{1-\mathrm{x}} \mathrm{N}$ or (f) a multi-layered structure of $\mathrm{GaN}$ and $\mathrm{Al}_{\mathrm{x}} \mathrm{Ga}_{1-\mathrm{x}} \mathrm{N}$ layers.

The GaN layer shown in Figure 2(d) was grown for $35 \mathrm{~min}$ at a susceptor temperature of $1075^{\circ} \mathrm{C}$ and for 2 min at a susceptor temperature of $1090^{\circ} \mathrm{C}$. The additional layer of $\mathrm{Al}_{10} \mathrm{Ga}_{90} \mathrm{~N}$ was grown for 20 min at $1090^{\circ} \mathrm{C}$. This alloy layer appears in the scanning electron micrographs as a slightly darker cap atop the GaN layer. To produce the heterostructure shown in Figure 2(e) a thin GaN layer was grown for 2 min at a susceptor temperature of $1070^{\circ} \mathrm{C}$ and for 2 min at $1090^{\circ} \mathrm{C}$. The $\mathrm{Al}_{10} \mathrm{Ga}_{90} \mathrm{~N}$ was deposited using three growth steps at the susceptor temperatures and times of $1090^{\circ} \mathrm{C}$ and $2 \mathrm{~min}, 1110^{\circ} \mathrm{C}$ and $50 \mathrm{~min}$, and $1090^{\circ} \mathrm{C}$ and $30 \mathrm{~min}$. The second step was employed to force the $\mathrm{Al}_{10} \mathrm{Ga}_{90} \mathrm{~N}$ to grow laterally and coalesce; the third step was used to grow the film vertically. The growth rate of $\mathrm{Al}_{10} \mathrm{Ga}_{90} \mathrm{~N}$ films was markedly lower at both $1090^{\circ} \mathrm{C}$ and $1110^{\circ} \mathrm{C}$ than that of the $\mathrm{GaN}$ at any temperature employed in this study. A multilayered structure shown in Figure 2(f) was also realized using several different growth parameter. 


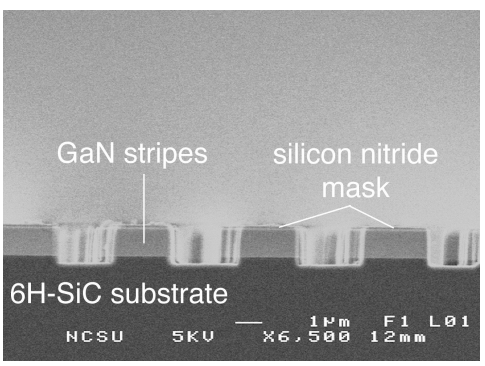

a

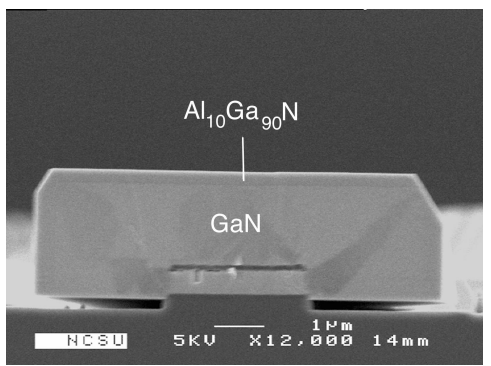

d

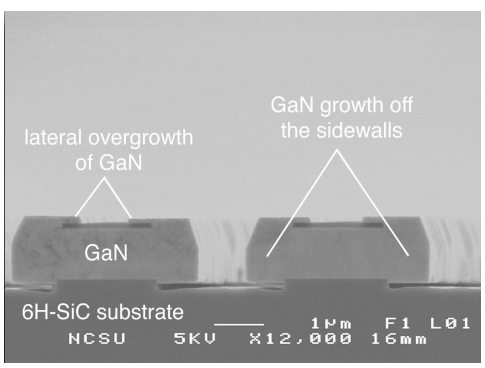

h

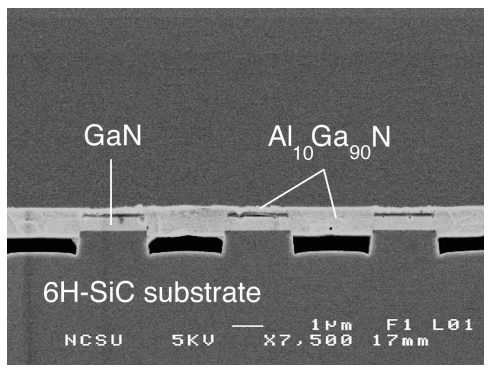

P

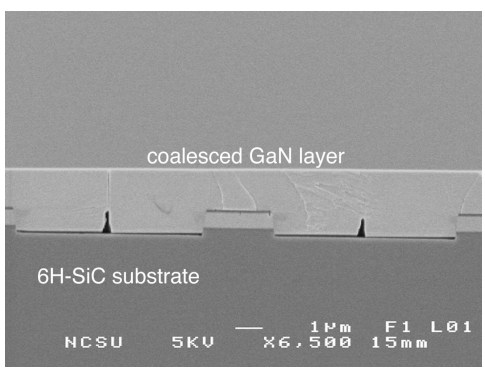

$c$

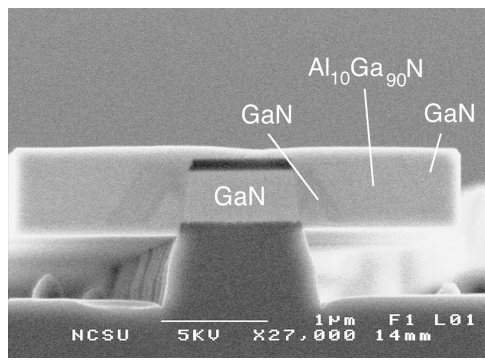

f

Figure 2. Scanning electron micrographs of (a) etched columnar forms in a GaN seed layer, (b) lateral and vertical growth phenomena during pendeo-epitaxy, (c) a continuous coalesced layer of GaN, (d) a discrete bi-layer structure of $\mathrm{GaN}$ and $\mathrm{Al}_{10} \mathrm{Ga}_{90} \mathrm{~N}$, (e) a continuous coalesced layer of $\mathrm{Al}_{10} \mathrm{Ga}_{90} \mathrm{~N}$, and (f) a multilayered structure of $\mathrm{GaN} / \mathrm{Al}_{10} \mathrm{Ga}_{90} \mathrm{~N} / \mathrm{GaN}$.

The first layer of $\mathrm{GaN}$ was grown at susceptor temperatures of $1075^{\circ} \mathrm{C}$ for $3 \mathrm{~min}$ and $1090^{\circ} \mathrm{C}$ for $2 \mathrm{~min}$. The subsequent layer of $\mathrm{Al}_{10} \mathrm{Ga}_{90} \mathrm{~N}$ was grown using susceptor temperatures of $1090^{\circ} \mathrm{C}$ for 10 min and $1075^{\circ} \mathrm{C}$ for $5 \mathrm{~min}$. The temperature during the $\mathrm{Al}_{10} \mathrm{Ga}_{90} \mathrm{~N}$ growth was not increased to $1110^{\circ} \mathrm{C}$ to limit the lateral growth. The additional layer of $\mathrm{GaN}$ was grown at a susceptor temperature of $1075^{\circ} \mathrm{C}$ for $10 \mathrm{~min}$. The scanning electron micrograph in Figure 2(f) shows $60^{\circ}$ interface planes between each layer. During the $\mathrm{GaN}$ growth the angled planes were growing out to the $(11 \overline{2} 0)$ plane to form the side walls of the structure.

The bi-layer structure in Figure 3 consists of a GaN layer grown at susceptor temperatures of $1075^{\circ} \mathrm{C}$ for $35 \mathrm{~min}$ and $1090^{\circ} \mathrm{C}$ for $2 \mathrm{~min}$ and a capping layer of $\mathrm{Al}_{5} \mathrm{Ga}_{95} \mathrm{~N}$ grown for 20 min at a susceptor temperature of $1090^{\circ} \mathrm{C}$. This structure possessed extremely smooth (0001) top and (11) 0 ) side wall surfaces, as shown in the AFM images in Figure 4. The RMS roughness values of the (0001) plane and the $(1 \overline{12} 0)$ side walls were $0.548 \mathrm{~nm}$ and $0.099 \mathrm{~nm}$, respectively. 


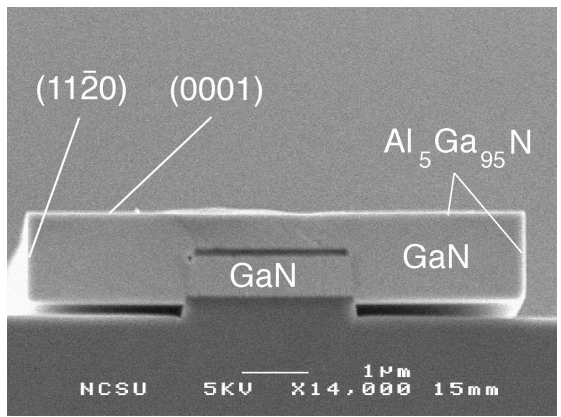

Figure 3. Scanning electron micrograph of a bi-layer structure of $\mathrm{GaN}$ and $\mathrm{Al}_{5} \mathrm{Ga}_{95} \mathrm{~N}$ used for $\mathrm{AFM}$ measurements.

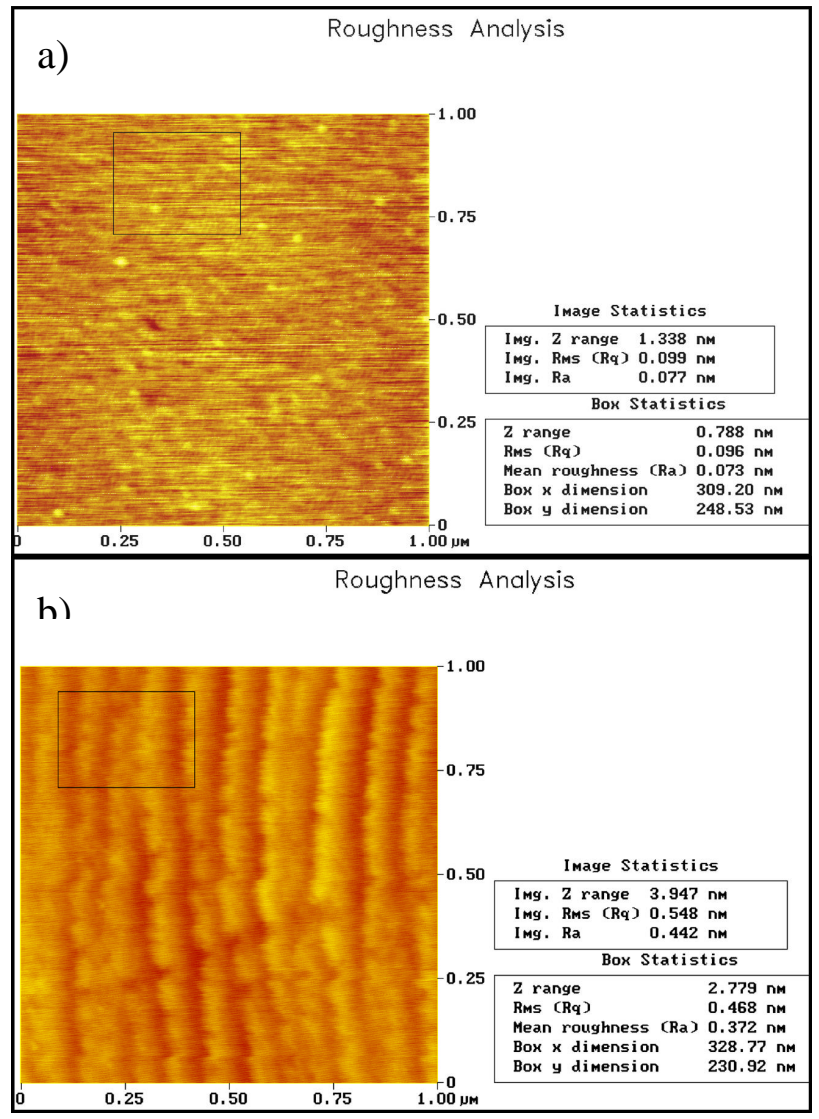

Figure 4.

Atomic force

micrographs of

a) the surface of

the side walls

represented by

the (1120)

plane,

b) the top surface

of the structure

represented by

the $(\mathrm{n} \cap \mathrm{n}) \mathrm{1})$ 


\section{CONCLUSIONS}

Pendeo-epitaxial growth of layered structures of $\mathrm{GaN}$ and $\mathrm{Al}_{\mathrm{x}} \mathrm{Ga}_{1-\mathrm{x}} \mathrm{N}$ has been achieved. The process steps for growing continuous coalesced $\mathrm{GaN}$ and $\mathrm{Al}_{x} \mathrm{Ga}_{1-\mathrm{x}} \mathrm{N}$ layers have been discussed in detail. According to this steps the process routes for growing layered structures of $\mathrm{GaN}$ and $\mathrm{Al}_{\mathrm{x}} \mathrm{Ga}_{1-\mathrm{x}} \mathrm{N}$ have been introduced and discussed. The top surface and side walls of this structures have been characterized by atomic force microscopy and a RMS roughness of $0.548 \mathrm{~nm}$ and $0.099 \mathrm{~nm}$, respectively, has been reported.

\section{ACKNOWLEDGMENTS}

The authors express their appreciation to Cree Research, Inc. for supplying the $\mathrm{SiC}$ wafers. This work was supported by the Office of Naval Research under the contract \# N00014-96-1-0765, N00014-98-1-0384 with C. Wood as technical monitor, and N00014-98-1-0654 with J. Zolper as technical monitor.

\section{REFERENCES}

1. K. J. Linthicum, T. Gehrke, D. B. Thomson, K. M. Tracy, E. P. Carlson, T. Smith, T. S. Zheleva, R. F. Davis, Mat. Res. Soc. Symp., this volume

2. D. B. Thomson, T. Gehrke, K. J. Linthicum, P. Rajagopal, T. S. Zheleva, R. F. Davis, Mat. Res. Soc. Symp., this volume

3. T. S. Zheleva, D. B. Thomson, T. Gehrke, K. J. Linthicum, P. Rajagopal, S. Smith, R. F. Davis, Mat. Res. Soc. Symp., this volume

4. K. J. Linthicum, T. Gehrke, D. B. Thomson, E. P. Carlson, P. Rajagopal, T. Smith, R. F. Davis, Appl. Phys. Lett., submitted Nov. 1998

5. T. S. Zheleva, D. B. Thomson, K. J. Linthicum, S. Smith, R. F. Davis, J. of Electr. Mat., submitted Nov. 1998 